\title{
OBITUARY
}

\section{Professor Norman Philbrick}

Professor Norman Philbrick of California, a founder member and benefactor of the Federation, died in January at the age of 73 .

Professor Philbrick graduated from Pomona College in 1935 and subsequently taught there until I 94 I. He earned his Master's Degree at Stanford University in 1942 and joined the Faculty there in 1943 . He served as Chairman of Speech and Drama during $1954^{-1} 1962$ and retired in 1968 to devote his attention to the development of his private theatre library and collection, one of the richest in private hands in the United States. Following a summer visit to London, he was present at the official ceremony when the entire collection was donated to Pomona College in his name and in that of his wife who predeceased him.

Apart from his academic career he was the author of four three-act plays, and of pageant dramas. He also served and directed at the Pasadena Playhouse.

$\mathrm{He}$ was active in many professional organizations: the American Society for Theatre Research; the American Educational Theatre Association: the International Institute of Arts and Letters, and the Speech Association of America. He was a founder member of the Federation and gave generous support to many of its activities, especially the meeting of the General Assembly in New York in 1969, and the Conference to be held in October this year.

He will be mourned and remembered by friends as a very private person of modesty and gentle humour: the Norman and Jerry Philbrick Library, now openly accessible, stands as a public memorial to a dedicated scholar and man of theatre. 